\title{
Mengidentifikasi Karakter "Menghargai Prestasi" Peserta Didik Kelas VIII SMP N 5 Muaro Jambi
}

\author{
Wenny Sutomo ${ }^{1}$, Vetty Milyani ${ }^{2}$ \\ ${ }^{1}$ SMP N 8 Batanghari, Kabupaten Batanghari, Provinsi Jambi \\ ${ }^{2}$ Prodi Pendidikan Fisika FKIP Universitas Jambi \\ lauda.aj.ws@gmail.com \\ 2vettymilyani10@gmail.com
}

\begin{abstract}
ABSTRAK
Penelitian ini bertujuan untuk mengidentifikasikan karakter peserta didik, terutama karakter menghargai prestasi peserta didik kelas VIII SMP N 5 Muaro Jambi. Pendekatan yang digunakan dalam penelitian ini adalah pendekatan kuantitatif. Sedangkan jenis penelitian yang digunakan yaitu jenis penelitian survei dengan instrumen penelitian berupa angket. Subjek penelitian ini adalah peserta didik kelas VIII A dan VIII E SMP N 5 Muaro Jambi, dengan jumlah total responden sebanyak 45 responden. Teknik analisis data yang digunakan yaitu teknik analisis statistik deskriptif. Sedangkan hasil penelitian menunjukkan bahwa angket karakter menghargai prestasi peserta didik digolongkan dalam kategori "sangat baik". Pada kelas VIII A, terdapat 16,7 \% pernyataan yang dijawab dengan baik oleh peserta didik, dan terdapat $83,3 \%$ pernyataan yang dijawab dengan sangat baik oleh peserta didik. Sedangkan pada kelas VIII E, terdapat $25,9 \%$ pernyataan yang dijawab dengan baik oleh peserta didik, dan terdapat $74,1 \%$ pernyataan yang dijawab dengan sangat baik oleh peserta didik. Berdasarkan hasil angket tersebut, dapat disimpulkan bahwa peserta didik SMP N 5 Muaro Jambi, khususnya kelas VIII A dan VIII E, telah memiliki sikap yang sangat baik dalam menghargai prestasi.
\end{abstract}

Kata Kunci: Karakter, Menghargai Prestasi, Peserta Didik, Pendidikan

\section{ABSTRACT}

This study aims to identify the character of students, especially the character of respecting the achievements of class VIII students of SMP N 5 Muaro Jambi. The approach used in this study is a quantitative approach. While the type of research used is the type of survey research with research instruments in the form of questionnaires. The subjects of this study were students of class VIII A and VIII E SMP N 5 Muaro Jambi, with a total number of respondents as many as 45 respondents. The data analysis technique used is descriptive statistical. The results of the study indicate that character questionnaires value achievement classified in the category of "very good". In class VIII A, there were $16.7 \%$ statements that were answered well by students, and there were $83.3 \%$ statements that were answered very well by students. Whereas in class VIII E, there were $25.9 \%$ of statements answered well by students, and there were $74.1 \%$ statements that were answered very well by students. Based on the results of the questionnaire, it can be concluded that the students of SMP N 5 Muaro Jambi, especially classes VIII A and VIII E, have had a very good attitude in respecting achievement.

Keywords: Character, Respect for Achievement, Students, Education

\section{PENDAHULUAN}

Pendidikan merupakan suatu hal yang sangat menarik untuk dijadikan topik pembicaraan, baik itu dikalangan umum ataupun akademisi. Pendidikan umumnya adalah suatu kegiatan nyata yang mengandalkan sumber daya manusia terutama peserta didik, untuk dapat ditumbuhkembangkan melalui bimbingan dan pemberian fasilitas belajar (Astalini, dkk., 2018:59). Apabila diartikan dalam segi proses, pendidikan merupakan suatu proses yang dapat mempengaruhi peserta didik supaya dapat menyesuaikan dengan lingkungan sekitar dan dapat menimbulkan perubahan perilaku, baik itu perilaku kognitif, psikomotorik, ataupun afektif (Hasnah, 2012:131). Pendidikan juga dapat dikatakan sebagai kunci dari keberhasilan para peserta didik. Dengan 
adanya pendidikan, para peserta didik bisa lebih melek dengan dunia luar dan mampu bersaing dalam bidang apapun. Sedangkan tanpa adanya pendidikan, peserta didik akan semakin buta dengan dunia luar dan tidak akan mampu bersaing dalam bidang apapun. Oleh karena itu, pendidikan sangat berperan penting dalam keberhasilan para peserta didik (Desstya, dkk., 2017:1).

Ilmu pendidikan dapat diperoleh darimana saja, salah satunya melalui jenjang pendidikan. Jenjang pendidikan adalah suatu tahapan pendidikan yang ditetapkan berdasarkan tingkat pemahaman, keluasan, serta kedalaman materi yang diajarkan kepada para peserta didik (Kadir, 2012:220). Jenjang pendidikan yang dimaksud antara lain PAUD, TK, SD, SMP, SMA, Perguruan Tinggi, dan Pascasarjana. Di setiap jenjang pendidikan tentu memiliki perbedaan yang mendalam dalam setiap tingkatnya. Salah satu jenjang pendidikan yang menarik perhatian umum adalah jenjang pendidikan SMP. Pendidikan di tingkat SMP dapat dikatakan kurang optimal, terutama untuk para peserta didik. Peserta didik di SMP masih kurang peduli dengan adanya pendidikan atau proses pembelajaran, justru mereka merasakan kebosanan saat proses pembelajaran berlangsung (Jusita, 2016:22).

Setiap pendidikan di berbagai dunia pasti memiliki pacuan ataupun pedoman dalam menjalankan sistem pendidikannya. Pendidikan di Indonesia memiliki pacuan ataupun pedoman berupa kurikulum, yaitu Kurikulum 2013. Dalam Kurikulum 2013, terdapat 3 ranah penilaian, yaitu penilaian kognitif, psikomotorik, dan afektif. Dari ketiga ranah penilaian tersebut, penilaian afektif yang paling populer diperbincangkan dalam dunia pendidikan. Penilaian afektif juga biasa disebut dengan penilaian sikap atau penilaian karakter. Penilaian sikap dapat diartikan sebagai bentuk pandangan seseorang terhadap suatu objek yang dapat disampaikan melalui ekspresi suka ataupun tidak (Kurniawan, dkk., 2018:124). Sementara itu, karakter dapat diartikan sebagai nilai-nilai baik yang tercerminkan pada perilaku peserta didik. Karakter juga dapat dikatakan sebagai suatu sifat yang menjadi pembeda antara satu dengan yang lain (Mumpuniarti, 2012:252).

Apabila dihubungkan dengan pendidikan, maka pendidikan karakter dapat dikatakan sebagai pendidikan nilai, baik itu pendidikan moral, pendidikan watak, dan pendidikan perilaku budi pekerti. Pemaknaan pendidikan moral disini apabila dikaitkan dengan dunia pendidikan memiliki arti bahwa peserta didik diharuskan untuk mengikuti jenjang pendidikan supaya memiliki moral atau karakter yang baik (Amrah, 2013:20). Pendidikan karakter ini juga selalu berpedoman pada karakter dasar peserta didik, yang sejatinya berawal dari nilai-nilai agama para peserta didik tersebut (Setiawati, 2017:348). But, in fact, the character also does not develop by itself. In each individual, character development is influenced by internal factors and external factors (Khoiri, 2018:103).

Memasuki abad ke 21, dunia pendidikan mulai beralih dari pendidikan berbasis nilai menjadi pendidikan berbasis karakter. Hal ini dilakukan karena di dalam dunia pendidikan, terdapat banyak peristiwa yang banyak merendahkan harkat dan martabat manusia, dapat dikatakan bahwa pendidikan di Indonesia sedang mengalami krisis karakter. Tingkat moralitas yang rendah, ketidakadilan yang merajalela, dan tingkat solidaritas yang rendah telah mewabah dalam dunia pendidikan (Kardiyem, 2013:48). Oleh karena itu, pemerintah harus turun tangan dalam menindaklanjuti peristiwa ini. Selain itu, untuk menerapkan pendidikan berbasis karakter juga harus memerlukan proses yang panjang. Hal ini dikarenakan bahwa membangun karakter bukan suatu hal instan yang dapat langsung dirasakan setelah pendidikan itu diberikan (Dewi dan Handayani, 2019:1).

Untuk menanggulangi pengikisan karakter peserta didik, maka dibuatlah suatu instrumen pendidikan seperti pemberian angket untuk mengetahui kedalaman karakter peserta didik, mengerahkan pengajar yang telah berpengalaman, memberikan sumber belajar yang jelas, dan memberikan tindakan pembelajaran seperti strategi pembelajaran, metode pembelajaran, dan model pembelajaran yang tepat bagi para peserta didik (Fauzi, dkk., 2017:28). Penilaian karakter bisa muncul dikarenakan belum berhasilnya sistem pendidikan dalam menciptakan berbagai lulusan yang unggul dalam kemampuan kognitif, psikomotorik, dan juga afektif (Febrianshari, dkk., 2018:89). Pendidikan karakter juga tidak hanya sekedar mengajarkan hal yang benar atau hal yang salah, namun lebih mengajarkan dan menanamkan perilaku sehari-hari supaya peserta didik bisa lebih paham, mengerti, dan berpengalaman (Supranoto, 2015:36). 
Berhubungan dengan pendidikan karakter ataupun pendidikan moral, pemerintah telah memberikan respon positif dengan diputuskannya Kebijakan Nasional Pembangunan Karakter Bangsa yang berisikan tentang arah kebijakan, tahapan, dan strategi yang digunakan untuk pembangunan karakter bangsa, khususnya para peserta didik (Amir, 2017:128). Menurut Supranoto (2015:36), Kemendiknas telah merumuskan 18 item karakter yang akan ditanamkan pada setiap peserta didik. Kedelapan belas karakter tersebut antara lain:

1. Religius

2. Jujur

3. Toleransi

4. Disiplin

5. Kerja Keras

6. Kreatif

7. Mandiri

8. Demokratis

9. Rasa Ingin Tahu

10. Semangat Kebangsaan

11. Cinta Tanah Air

12. Menghargai Prestasi

13. Bersahabat/Komunikatif

14. Cinta Damai

15. Gemar Membaca

16. Peduli Lingkungan

17. Peduli Sosial

18. Tanggung Jawab

Diantara kedelapan belas item karakter tersebut, terdapat salah satu karakter yang menarik perhatian, yaitu karakter menghargai prestasi. Karakter menghargai prestasi sangat populer diperbincangkan dalam dunia pendidikan. Karakter ini lebih menekankan untuk mendorong dirinya sendiri dalam melakukan sesuatu yang berguna dalam masyarakat, dan bersedia mengakui keberadaan orang lain, serta menghormati atau mengapresiasi keberhasilan yang telah dicapai orang lain. Menghargai prestasi merupakan suatu karakter yang harus ditanamkan sejak dini dalam diri peserta didik. Hal ini dikarenakan banyak peserta didik yang meremehkan atau mencaci maki prestasi yang dimiliki oleh peserta didik yang lain. Tidak sedikit pula peserta didik yang meniru hasil karya orang lain (plagiat) dan tidak percaya diri dengan hasil karyanya sendiri.

Karakter ini sangat mendorong peserta didik untuk dapat meningkatkan kognitif, psikomotorik, dan afektif peserta didik. Peserta didik merasa lebih tertantang untuk belajar lebih giat lagi dan merasa lebih terpacu untuk memecahkan persoalan-persoalan yang sulit.
Hal ini dilakukan peserta didik guna memaksimalkan prestasi mereka untuk dapat bersaing terhadap sesama.

Tujuan penelitian ini adalah untuk mendeskripsikan atau mengidentifikasikan mengenai karakter peserta didik, terutama karakter menghargai prestasi peserta didik kelas VIII SMP N 5 Muaro Jambi, khususnya kelas VIII A dan VIII E. Penelitian ini juga membahas mengenai statistika deskriptif seperti Mean, Modus, Median, dan parameter statistika yang lainnya. Berdasarkan pernyataan tersebut, peneliti ingin mengetahui bagaimana hasil angket para peserta didik berdasarkan perhitungan menggunakan parameter statistika deskriptif, dan peneliti ingin melihat apakah para peserta didik telah memiliki tingkat kesadaran yang tinggi terhadap prestasi atau justru sebaliknya.

METODE PENELITIAN
Pendekatan dalam penelitian ini
menggunakan pendekatan kuantitatif. Pendekatan kuantitatif merupakan suatu pendekatan penelitian yang bersifat objektif dengan menggunakan metode statistik dalam pengujiannya (Hermawan dan Yusran, 2017:5). Data yang digunakan merupakan data yang bersifat angka atau bilangan. Dalam dunia statistika, data tersebut dapat dikatakan sebagai data numerik.

Penelitian ini juga menggunakan jenis penelitian survei. Penelitian survei merupakan salah satu jenis penelitian yang pengambilan datanya menggunakan pertanyaan-pertanyaan tertulis, bukan pertanyaan lisan (Rukajat, 2018:143).

Penelitian dilaksanakan pada tanggal 22 Maret 2019 yang bertempat di SMP N 5 Muaro Jambi, Kabupaten Muaro Jambi, Provinsi Jambi. Populasi dalam penelitian ini adalah peserta didik kelas VIII SMP N 5 Muaro Jambi. Sedangkan respondennya yaitu peserta didik kelas VIII A SMP N 5 Muaro Jambi dan peserta didik kelas VIII E SMP N 5 Muaro Jambi. Jumlah total responden adalah sebanyak 45 responden, dengan 18 responden berasal dari kelas VIII A dan 27 responden berasal dari kelas VIII E.

Teknik pengumpulan data pada penelitian ini yaitu menggunakan angket. Angket yang digunakan dalam penelitian ini merupakan angket karakter "Menghargai Prestasi" yang diadopsi dari skripsi (Anisabellah, 2017), dimana angket tersebut terdiri dari 30 item pernyataan yang telah lulus uji validasi dan reliabilitas. Namun, dalam 
penelitian ini hanya diadopsi 25 item pernyataan. Jenis angket yang digunakan yaitu angket tertutup berupa pernyataan mengenai kesadaran para peserta didik dalam menghargai suatu prestasi. Sedangkan alat dan bahan utama dalam penelitian ini adalah data kuantitatif yang diambil langsung dari responden.

Dalam teknik analisis data, data yang diperoleh akan diolah menggunakan statistik deskriptif dengan bantuan aplikasi SPSS. Sedangkan untuk penilaian angket, dapat dilakukan dengan menggunakan penilaian atau pengukuran skala Likert. Menurut Muhidin (2017:5), penilaian skala Likert meliputi:

1. Selalu (S)

2. Sering $(\mathrm{SR})$

3. Jarang $(\mathrm{J})$

4. Tidak Pernah (TP)

Dimana skor atau nilai untuk skala tersebut antara lain:

1. Selalu $=4$

2. Sering $=3$

3. Jarang $=2$

4. Tidak Pernah $=1$

Untuk pengukuran pernyataan (+), diberi nilai 4,3,2,1 dimulai dari skala Selalu (S). Namun, untuk pengukuran pernyataan (-), diberi nilai 4,3,2,1 dimulai dari skala Tidak Pernah (TP).

\section{HASIL \& PEMBAHASAN} Hasil

Hasil analisis statistik deskriptif menggunakan SPSS dari data angket karakter menghargai prestasi peserta didik kelas VIII A SMP N 5 Muaro Jambi dapat dilihat pada tabel berikut:

Tabel 1. Statistik Deskriptif Angket Karakter "Menghargai Prestasi" Peserta Didik Kelas VIII A SMP N 5 Muaro Jambi

\begin{tabular}{lc}
\hline \multicolumn{1}{c}{ Parameter } & Hasil \\
\hline Mean & 86,94 \\
Median & 87,50 \\
Modus & 86 \\
Standar Deviasi & 6,494 \\
Rentang & 25 \\
Minimum & 72 \\
Maksimum & 97
\end{tabular}

Tabel 2. Klasifikasi Angket Karakter "Menghargai Prestasi" Peserta Didik Kelas VIII A SMP N 5 Muaro Jambi

Klasifikasi Persentase

\begin{tabular}{|c|c|c|c|}
\hline Skor & Kategori & Frekuensi & $(\%)$ \\
\hline & Sangat & & \\
\hline $25-43,75$ & $\begin{array}{l}\text { Tidak } \\
\text { Baik }\end{array}$ & 0 & $0 \%$ \\
\hline $43,76-62,5$ & $\begin{array}{l}\text { Tidak } \\
\text { Baik }\end{array}$ & 0 & $0 \%$ \\
\hline $62,6-81,25$ & Baik & 3 & $16,7 \%$ \\
\hline $81,26-100$ & $\begin{array}{c}\text { Sangat } \\
\text { Baik }\end{array}$ & 15 & $83,3 \%$ \\
\hline \multicolumn{2}{|c|}{ Jumlah } & 18 & $100 \%$ \\
\hline
\end{tabular}

Sedangkan hasil analisis statistik deskriptif menggunakan SPSS dari data angket karakter menghargai prestasi peserta didik kelas VIII E SMP N 5 Muaro Jambi dapat dilihat pada tabel berikut:

Tabel 3. Statistik Deskriptif Angket Karakter "Menghargai Prestasi" Peserta Didik Kelas VIII E SMP N 5 Muaro Jambi

\begin{tabular}{lc}
\multicolumn{1}{c}{ Parameter } & Hasil \\
\hline Mean & 84,74 \\
Median & 85 \\
Modus & 78 \\
Standar Deviasi & 4,528 \\
Rentang & 15 \\
Minimum & 77 \\
Maksimum & 92
\end{tabular}

Tabel 4. Klasifikasi Angket Karakter "Menghargai Prestasi" Peserta Didik Kelas VIII E SMP N 5 Muaro Jambi

\begin{tabular}{|c|c|c|c|}
\hline \multicolumn{3}{|c|}{ Klasifikasi } & \multirow{2}{*}{$\begin{array}{c}\text { Persentase } \\
(\%)\end{array}$} \\
\hline Skor & Kategori & Frekuensi & \\
\hline $25-43,75$ & $\begin{array}{c}\text { Sangat } \\
\text { Tidak } \\
\text { Baik }\end{array}$ & 0 & $0 \%$ \\
\hline $43,76-62,5$ & $\begin{array}{l}\text { Tidak } \\
\text { Baik }\end{array}$ & 0 & $0 \%$ \\
\hline $62,6-81,25$ & Baik & 7 & $25,9 \%$ \\
\hline $81,26-100$ & $\begin{array}{c}\text { Sangat } \\
\text { Baik }\end{array}$ & 20 & $74,1 \%$ \\
\hline \multicolumn{2}{|c|}{ Jumlah } & 27 & $100 \%$ \\
\hline
\end{tabular}

\section{Pembahasan}

Penelitian ini bertujuan untuk mendeskripsikan atau mengidentifikasikan mengenai karakter peserta didik, terutama karakter menghargai prestasi para peserta didik kelas VIII SMP N 5 Muaro Jambi, khususnya kelas VIII A dan VIII E. Penelitian ini dilakukan dengan cara menyebarkan angket kepada para peserta didik. 
Untuk mengidentifikasi karakter menghargai prestasi peserta didik, peneliti menggunakan bantuan aplikasi atau software SPSS untuk mempermudah perhitungan secara statistik. Parameter yang dapat dicari menggunakan software SPSS dapat berupa mean, median, modus, standar deviasi, rentang, nilai minimum, dan nilai maksimum. Selain itu, peneliti juga dapat mengidentifikasi tingkat menghargai peserta didik menggunakan skala likert.

Berdasarkan data hasil pada Tabel 1, yaitu data angket karakter peserta didik kelas VIII A didapatkan bahwa nilai rata-rata (mean) dari 18 responden adalah sebesar 86,94. Sedangkan untuk nilai tengah (median) didapatkan sebesar 87,50. Sementara untuk nilai yang sering muncul (modus) didapatkan sebesar 86. Untuk standar deviasi didapatkan sebesar 6,494. Rentang yang didapatkan sebesar 25. Nilai minimum yang didapatkan sebesar 72, dan nilai maksimum yang didapatkan sebesar 97. Untuk menganalisis data tersebut, kita bisa melihat dari nilai mean, modus, dan standar deviasi. Dari data tersebut didapatkan nilai mean sebesar 86,94, dimana nilai tersebut berada pada kategori "sangat baik". Didapatkan pula nilai modus sebesar 86 yang juga berada pada kategori "sangat baik". Selain itu, kita juga bisa melihat dari nilai standar deviasi dari data tersebut, yaitu sebesar 6,494. Apabila nilai standar deviasi lebih kecil daripada nilai mean, maka data tersebut dapat dikatakan valid. Dari pernyataan tersebut, dapat dikatakan bahwa data tersebut dikatakan valid, hal ini dikarenakan bahwa nilai standar deviasi lebih kecil daripada nilai mean, yaitu $6,494<86,94$. Berdasarkan hasil data tersebut, dapat disimpulkan bahwa tingkat karakter peserta didik kelas VIII A dalam menghargai prestasi dapat digolongkan ke dalam kategori "sangat baik".

Namun, kita perlu meninjau kembali dari segi penilaian skala likert. Berdasarkan data hasil pada Tabel 2, didapatkan data bahwa terdapat 3 peserta didik yang menjawab angket dengan baik, dengan persentase $16,7 \%$. Selain itu, terdapat pula 15 peserta didik yang menjawab angket dengan sangat baik, dengan persentase $83,3 \%$. Berdasarkan data tersebut, dapat disimpulkan pula bahwa tingkat karakter peserta didik kelas VIII A dalam menghargai prestasi sudah tergolong "sangat baik".

Sedangkan data hasil pada Tabel 3, yaitu data angket karakter peserta didik kelas VIII E didapatkan bahwa nilai rata-rata (mean) dari 27 responden adalah sebesar 84,74.
Sedangkan untuk nilai tengah (median) didapatkan sebesar 85. Modus didapatkan sebesar 78. Untuk standar deviasi didapatkan sebesar 4,528. Rentang yang didapatkan sebesar 15. Nilai minimum yang didapatkan sebesar 77, dan nilai maksimum yang didapatkan sebesar 92. Untuk menganalisis data tersebut, kita bisa melihat dari nilai mean, modus, dan standar deviasi. Dari data tersebut didapatkan nilai mean sebesar 84,74 , dimana nilai tersebut berada pada kategori "sangat baik". Didapatkan pula nilai modus sebesar 78, yang berada pada kategori "baik". Selain itu, kita juga bisa melihat dari nilai standar deviasi dari data tersebut, yaitu sebesar 4,528. Apabila nilai standar deviasi lebih kecil daripada nilai mean, maka data tersebut dapat dikatakan valid. Dari pernyataan tersebut, dapat dikatakan bahwa data tersebut dikatakan valid, hal ini dikarenakan bahwa nilai standar deviasi lebih kecil daripada nilai mean, yaitu 4,528 < 84,74 . Berdasarkan hasil data tersebut, dapat disimpulkan bahwa tingkat karakter peserta didik kelas VIII E dalam menghargai prestasi dapat digolongkan ke dalam kategori "sangat baik".

Namun, kita perlu meninjau kembali dari segi penilaian skala likert. Berdasarkan data hasil pada Tabel 4, didapatkan data bahwa terdapat 7 peserta didik yang menjawab angket dengan baik, dengan persentase $25,9 \%$. Selain itu, terdapat pula 20 peserta didik yang menjawab angket dengan sangat baik, dengan persentase $74,1 \%$. Berdasarkan data tersebut, dapat disimpulkan pula bahwa tingkat karakter peserta didik kelas VIII E dalam menghargai prestasi sudah tergolong "sangat baik".

Pendidikan karakter sangat penting sekali untuk diterapkan dalam diri peserta didik, khususnya sejak usia dini. Penerapannya juga bisa dilakukan dimana saja. Bisa diterapkan dalam lingkungan sekolah, lingkungan keluarga, atau bahkan lingkungan masyarakat. Hal ini dikarenakan tidak hanya guru yang dapat membantu menerapkan nilai karakter tersebut, tetapi orangtua, masyarakat sekitar, dan sahabat-sahabat atau teman-teman di sekeliling kita juga bisa membantu menerapkan nilai karakter tersebut. Namun, belakangan ini pendidikan karakter sangat ditekankan untuk diterapkan dalam lembaga pendidikan. Hal ini dikarenakan sangat mirisnya karakter peserta didik terutama dalam dunia pendidikan. Karakter ini harus diterapkan pada masing-masing peserta didik dengan berbagai proses. Penanaman karakter tidak bisa dilakukan secara instan. Sedangkan 
aspek yang perlu diperhatikan dalam proses penanaman karakter ini adalah knowing, loving, dan acting dari masing-masing peserta didik (Kardiyem, 2013:48).

Kemendiknas telah membagi karakter menjadi 18 jenis karakter. Satu diantaranya adalah karakter menghargai prestasi. Menghargai prestasi juga merupakan salah satu karakter yang sangat menarik untuk diperbincangkan. Hal ini dikarenakan banyak peserta didik yang telah meremehkan atau mencemooh bahkan menghina prestasi yang dimiliki oleh peserta didik yang lain. Tidak sedikit pula peserta didik yang meniru hasil karya orang lain (plagiat) dan tidak percaya diri dengan hasil karyanya sendiri. Dalam penerapannya, penanaman nilai menghargai prestasi dapat dilihat dari seberapa pedulinya peserta didik tersebut dalam memberikan penghargaan kepada peserta didik lain yang berprestasi. Peserta didik tersebut juga bisa memberikan pujian, semangat atau dukungan terhadap peserta didik yang berprestasi supaya prestasi tersebut dapat dipertahankan. Pujian yang diberikan tersebut juga bisa memberikan motivasi dan semangat kembali supaya peserta didik yang berprestasi tersebut dapat terus berkarya dengan baik (Kurniawati dan Irsyadillah, 2018:109).

\section{KESIMPULAN \& SARAN}

\section{Kesimpulan}

Berdasarkan hasil analisis angket karakter menghargai prestasi peserta didik kelas VIII A dan kelas VIII E SMP N 5 Muaro Jambi, dapat dikatakan bahwa tingkat kepedulian peserta didik dalam menghargai prestasi terhadap sesama sudah tergolong sangat baik. Hal ini dibuktikan dengan statistik deskriptif yang telah dicari menggunakan SPSS. Pada kelas VIII A, didapatkan hasil mean sebesar 86,94, median sebesar 87,50, modus sebesar 86, standar deviasi sebesar 6,494 , rentang sebesar 25 , nilai minimum sebesar 72, dan nilai maksimum sebesar 97. Hal ini juga dapat dibuktikan dengan klasifikasi dari angket karakter tersebut, didapatkan data bahwa terdapat terdapat 16,7 $\%$ peserta didik yang menjawab angket dengan baik, dan terdapat $83,3 \%$ peserta didik yang menjawab angket dengan sangat baik. Sedangkan pada kelas VIII E, didapatkan hasil mean sebesar 84,74, median sebesar 85 , modus sebesar 78, standar deviasi sebesar 4,528, rentang sebesar 15 , nilai minimum sebesar 77 , dan nilai maksimum sebesar 92. Hal ini juga dapat dibuktikan dengan klasifikasi dari angket karakter tersebut, didapatkan data bahwa terdapat $25,9 \%$ peserta didik yang menjawab angket dengan baik, dan terdapat 74,1 \% peserta didik yang menjawab angket dengan sangat baik. Berdasarkan hasil angket tersebut, dapat disimpulkan bahwa peserta didik SMP N 5 Muaro Jambi, khususnya kelas VIII A dan VIII E, telah memiliki karakter yang sangat baik dalam menghargai prestasi.

\section{Saran}

Dalam penelitian ini, peneliti sangat menyadari bahwa penerapan nilai karakter, khususnya karakter menghargai prestasi sangat penting untuk diterapkan dalam diri peserta didik, terutama sejak usia dini. Untuk memahaminya, tentu sangat diperlukan kajiankajian yang dilakukan secara intensif. Oleh karena itu, peneliti berharap tulisan ini dapat dijadikan rujukan atau bahan tulisan bagi para peneliti yang lain untuk dapat membantu dalam membuat suatu tulisan atau artikel penelitian. Hal ini juga ditujukan supaya peneliti yang lain bisa lebih mendalami pemahaman mengenai karakter menghargai peserta didik.

\section{DAFTAR PUSTAKA}

Amir, Rudi. (2017). Membangun Karakter dalam Perayaan Budaya Lokal di Kabupaten Takalar. Jurnal Publikasi Pendidikan, 7(3), 127-133.

Amrah. (2013). Perkembangan Moral Anak Usia Sekolah Dasar. Jurnal Publikasi Pendidikan, 3(1), 20-25.

Anisabellah. (2017). Pengaruh Sikap Sosial Siswa Terhadap Prestasi Belajar Mata Pelajaran IPS Siswa Kelas VIII MTs AlMaarif 01 Singosari Malang. Skripsi. Malang: Universitas Islam Negeri Maulana Malik Ibrahim.

Astalini., Kurniawan, Dwi Agus., dan Sumaryanti. (2018). Sikap Siswa Terhadap Pelajaran Fisika di SMAN Kabupaten Batanghari. Jurnal Ilmu Pendidikan Fisika, 3(2), 59-64.

Desstya, Anatri., dkk. (2017). Refleksi Pendidikan IPA Sekolah Dasar di Indonesia (Relevansi Model Pendidikan Paulo Freire dengan Pendidikan IPA di Sekolah Dasar). Profesi Pendidikan Dasar, 4(1), 1-11.

Dewi, Trie Utari dan Handayani, Sri Lestari. (2019). Penanaman Nilai Karakter Melalui Permainan Outdoor bagi AnakAnak Usia Dini di Wilayah RW 01 Kelurahan Pekayon, Kecamatan Pasar 
Rebo, Jakarta Timur. Jurnal Publikasi Pendidikan, 9(1), 1-6.

Fauzi, Achmad Ryan., Zainuddin., dan Atok, Rosyid Al. (2017). Penguatan Karakter Rasa Ingin Tahu dan Peduli Sosial Melalaui Discovery Learning. Jurnal Teori dan Praksis Pembelajaran IPS, 2(2), 27-36.

Febrianshari, Deddy., dkk. (2018). Analisis Nilai-Nilai Pendidikan Karakter dalam Pembuatan Dompet Punch Zaman Now. Jurnal Pemikiran dan Pengembangan SD, 6(1), 88-95.

Hasnah. (2012). Paradigma Pendidikan Masa Depan. Jurnal Publikasi Pendidikan, 2(2), 130-138.

Hermawan, Asep dan Yusran, Husna Leila. (2017). Penelitian Bisnis: Pendekatan Kuantitatif. Depok: Kencana.

Jusita, Martina Lona. (2016). Pengembangan Nilai-Nilai Karakter dalam Aktivitas Belajar Menggunakan Media Pembelajaran "Pecango". Jurnal Teori dan Praksis Pembelajaran IPS, 1(1), 2226.

Kadir, Abdul. (2012). Dasar-Dasar Pendidikan Edisi Pertama. Jakarta: Prenadamedia Group.

Kardiyem. (2013). Internalisasi Pendidikan Karakter dalam Akuntansi (Inspirasi) Diary (Solusi Konservasi Moral). Jurnal Dinamika Akuntansi, 5(1), 47-54.

Khoiri, Qolbi. (2018). Dimensions of Islamic Education in the Prevention Bullying; Assessing in an Effort of Character Building for Children in School. Jurnal Publikasi Pendidikan, 8(2), 101-108.

Kurniawan, Dwi Agus., Astalini., dan Anggraini, Lika. (2018). Evaluasi Sikap Siswa SMP Terhadap IPA di Kabupaten Muaro Jambi. Jurnal Ilmiah DIDAKTIKA, 19(1), 124-139.

Kurniawati, Rizki dan Irsyadillah. (2018). Analisis Nilai Karakter dalam Teks Cerita Buku Pelajaran Siswa Sekolah Dasar. Master Bahasa, 6(2), 103-114.

Muhidin, Aeng. (2017). Statistika Pendidikan: Pendekatan Berbasis Kinerja. Tangerang: UNPAM Press.

Mumpuniarti. (2012). Pembelajaran Nilai Keberagaman dalam Pembentukan Karakter Siswa Sekolah Dasar Inklusi. Jurnal Pendidikan Karakter, 2(3), 248257.

Rukajat, Ajat. (2018). Pendekatan Penelitian Kuantitatif. Yogyakarta: Deepublish.
Setiawati, Nanda Ayu. (2017). Pendidikan Karakter sebagai Pilar Pembentukan Karakter Bangsa. Prosiding Seminar Nasional Tahunan Fakultas Ilmu Sosial Universitas Negeri Medan, 1(1), 348-352.

Supranoto, Heri. (2015). Implementasi Pendidikan Karakter Bangsa dalam Pembelajaran SMA. Jurnal Promosi, 3(1), 36-49. 